\title{
LEGAL PROTECTION OF ENVIRONMENTS IN THE REPUBLIC OF SERBIA
}

\author{
Vojislav Jović ${ }^{1}$, Olivera Milutinović ${ }^{2}$, Goran Kvrgić3 ${ }^{3}$ Dragan Manojlović ${ }^{4}$ \\ *Corresponding author E-mail: vjovicbg@gmail.com
}

\begin{abstract}
A R T I C L E I N F O
A B S T R A C T

Review Article

Received: 25 February 2021

Accepted: 19 April2021

doi:10.5937/ekoPolj2102517J

UDC 349.6:502.34(497.11)

Keywords:

environment, environmental tort, evidence, national legal standards, criminal justice

JEL: K3, K32, Q1, Q19

Forms of environmental protection in the Republic of Serbia, as a rule, include administrative, misdemeanor and criminal law protection. This paper deals with general considerations of criminal law protection of the environment, its significance and position in the criminal legislation of the Republic of Serbia, and the effects of the competent judicial and other bodies on its suppression. The research includes basic national legal standards in the field of criminal law protection of the environment and their chronological correlation. The paper contains an empirical research of statistical indicators within which the correlation of reported, accused and convicted persons (outcome of criminal proceedings) for crimes against the environment during the time period from 2006 to 2017 in the Republic of Serbia was investigated.
\end{abstract}

(C) 2021 EA. All rights reserved.

\section{Introduction}

The genesis development of environmental protection can be observed from two aspects. The first refers to the theoretical aspect, which includes theoretical research and contemplation of the environment, and the second includes legal protection, ie normative regulation of this area. If we look globally at therepresentation of enviromental problems (ecology) in theory (International Webster New EncyclopedicDictionary of English

1 Vojislav Jović, Ph.D., Associate Professor, Facuty of Menagement, Sremski Karlovci, Phone: +381 6313339 99, E-mail: vjovicbg@gmail.com, ORCID ID (https://orcid. org/0000-0002-4049-5103)

2 Olivera Milutinović, PhD, Associate Professor, Facuty of Menagement, Sremski Karlovci, Phone: +38165 24497 77, E-mail: olivera.milutinovic@famns.edu.rs, ORCID ID (https:// orcid.org/0000-0002-9677-9025)

3 Goran Kvrgić, Ph.D., Full Professor, Facuty of Menagement, Sremski Karlovci, Phone: +381 6073213 20, E-mail: goran.kvrgic@famns.edu.rs, ORCID ID (https://orcid.org/00000002-1261-4590)

4 Dragan Manojlović, Ph.D., Full Professor, Facuty of Menagement, Sremski Karlovci, Phone: +38163 70290 29, E-mail: savaskela@gmail.com, ORCID ID (https://orcid. org/0000-0002-6120-0220)

http://ea.bg.ac.rs 
Language, 1973), the initial records theorists usually link to the period of the second half of the nineteenth century, ie to the publication of German biologist Ernest Haeckel entitled "History of Nature" from 1866 (Lilić, Drenovak, 2010). It is an indisputable fact that during the period of industrialization, environmental protection was moved to the second plan, whereby the primary goal of global society being focused on industrial development and economic progress. In such concept, the balance within the so-called "magic triangle", which includes three basic elements: ecological balance, economic security and social justice, was obviously disturbed. The development of the theoretical framework of environmental protection has contributed to the creation of environmental law as a new autonomous legal branch, and on the other hand, environmental safety occupies an important place in this new normative concept and is directly determined by criminal law protection (Brock, 1991) Criminal law norms of ecological character find their ratio legis in the fact that criminal sanctions suppress illegal actions of individuals and legal entities in the field of environmental law (Ćemalović, Jović, 2015). In addition to the fact that at the end of the last and the beginning of this century, environmental law recorded sudden tendencies of development, some regulations indicate that elements of this branch of law existed in the initial phase of development of legal science in general. The first significant document from this area that directly prescribed a certain type of environmental protection is the Budva Statute, from the ninth century, whose original provision translated from Italian language is: "I order that no one may throw garbage from the hallway or from the terrace or throw it on the road in any street in the city, under threat of a fine of 12 dinars, thereof half of it belongs to the court and half to the municipality" (Luketić, Bujuklić, Vučković, 1988 \& Lukinović et al., 2020).

The subject of research in this paper includes the protection of basic natural values, ie protection of air, water (Petrović, Jović, Manojlović, 2015), land (Petrović, Jović, Manojlović, 2014) as well as flora and fauna. The main goal is to make a finding within the scientific description of legal provisions and empirical research of statistical indicators on the degree and scope of criminal law regulation of environmental protection and the efficiency of judicial and other bodies in the field of environmental protection. The research was conducted on the basis of available theoretical material, adopted legal regulations and published statistical bulletins.

\section{Methodology and material}

The methodological-theoretical framework in this paper is based on the application of scientific methods of historical, statistical, quantitative, qualitative, scientific description, correlation and methods of content analysis, which explore available sources in existing theory and empiricism on criminal environmental protection and what are the scope of that protection in the Republic of Serbia. Beside to the scientific goal the scope of legal protection which has to be explore, there is a social one, which could be called a strategic or broader reform goal, because it indicates the need for changes in scientific and professional understanding as well necessary changes in preinvestigation and criminal proceedings in Serbia, from this areas. Indicators from the 
research are: scientific and professional legal literature, the number of filed criminal charges by the competent authorities for the commission of criminal offenses against the environment; the number of indictments filed by the prosecution; and the number of convictions handed down by the competent courts (Republic Institute for statistics Bulletins "Adult perpetrators of criminal offenses - reports, charges, convictions: Bulletin No. 490/2006; Bulletin No. 502/2007; Bulletin No. 514/2008; Bulletin No. 529/2009; Bulletin No. 546/2010; Bulletin No. 558/2011,; Bulletin No. 576/2012; Bulletin No. 588/2013; Bulletin No. 603/2014; Bulletin No. 617/2015; Bulletin No. 629/2016; and Bulletin No. 643/2017.). From the structure of work, sources and indicators, subjects and goals of the research, a theoretical-hypothetical framework is imposed, that the professional practice of criminal protection with its products of investigation procedure-criminal reports and criminal procedure-indictments and verdicts does not provide adequate environmental protection in the Republic of Serbia.

\section{Results of theoretical research and discussions}

\section{Chronology of normative regulation of environmental protection}

The criminal legislation of medieval Serbia did not issued legal protection of the environment, while the provisions of Dušan's Legal Code (Radojčić, 1960), as a rule, represented a private reaction to a crime, and the framework of legal protection of the so-called "common good" was quite restrictive. Until the codification of national criminal legislation and the enactment of the "Criminal Penal Code" of 1860, and the enactment of the first modern Criminal Code from year 1947 ("Official Gazette of the FPRY", No. 106/1947), the field of environmental protection remained outside the scope criminal law regulations. By the provisions of the Criminal Code from year 1951 ("Official Gazette of the FPRY", No. 13/1951) refers to nine criminal offenses by which environment was protected (criminal offenses against the national economy), according to the object of protection known to today's criminal legislation These criminal offenses were issued according to the following legal qualification: neglect of land cultivation and raising cattle; pests in agriculture; production of harmful means for the treatment of livestock; negligent provision of veterinary assistance; transmission of infectious diseases in animals, plants and trees; contamination of animal feed or water; devastation of forests; illegal hunting and illegal fishing. Furthermore, the provisions of the Law on Amendments to the Criminal Code from year 1959 ("Official Gazette of the FPRY”, No. 30/1959) introduce certain changes for existing criminal offenses and the framework of environmental protection is expanded with new incriminations, issueded within two criminal offenses (criminal offense of destruction of orchards using harmful substances and criminal offense of forest theft). According to further chronology, we find out that until 1977, this area remained unchanged.

In the Criminal Code of 1977 ("Official Gazette of the SRS", No. 26/1977), criminal offenses against the environment were issued within two legal chapters, ie two groups of criminal offenses, as follows: 1) within framework of criminal offenses against 
human health and the human environment and 2) in the framework of crimes against the economy. In comparison with the Criminal Code from 1951 and 1959, we notice that the number of criminal offenses in this area has increased by one criminal offense, and that the names and legal characteristics of certain offenses have been changed. As for the penal policy, in the law from 1977, it was mitigated for some criminal acts and aggravated for some. Finally, the amendments to the Criminal Legal Code from 2003 ("Official Gazette of RS", No. 39/2003) new incriminations were introduced, ie two new criminal offenses within the group of criminal offenses against the economy, namely: destruction and damage to specially protected natural goods and the criminal offense of taking abroad, without a permit, a specially protected plant or animal species.

\section{New legal solutions in the field of criminal law of the environment protection}

With the adoption of the now valid Criminal Code from 2005 ("Official Gazette of RS", No. 85/2005), for the first time, all criminal offenses against the environment were unified and classified within a separate legal chapter. Compared to previous legal solutions, now, the framework of criminal law protection has been significantly expanded and penal policy has been tightened. With new legal solutions, environmental protection has, formally speaking, gained importance (Salzman, Thompson, 2003), creating preconditions for achieving the concept of stable environmental safety (Jović, et.al., 2019), which confirms the justification of the initiative of the eighties of the last century, in orderto integrate environmental factors into the concept of global security (Dimitrijević, 2010).

Crimes against the environment belong to the group of crimes that occupy the sixth place (out of a total of 23 groups) according to the number of issued acts in the Criminal Code, so they are characterized by their number and diversity, and criminal law theory classifies this type of crime into four categories (Čejović, 2006). The first category includes seven criminal offenses (general criminal offenses against the environment), which, as a rule, endanger the environment to the greatest extent. The following criminal offenses are classified in this category: environmental pollution; failure to take measures for eniveronmetal protection; illegal construction and commissioning of facilities and plants that pollute the environment; damage to facilities and devices for environmental protection; environmental damage; destruction, damage, taking abroad and bringing into Serbia a protected natural good and the criminal offense of violation of the right to information about the state of the environment. The second category (criminal offenses related to hazardous substances) includes two criminal offenses, namely: introduction of hazardous substances into Serbia and illicit processing, disposal and storage of hazardous substances and the criminal offense of illicit construction of nuclear facilities, while the third category (criminal offenses against flora and fauna), also includes the following seven criminal offenses: killing and abusing animals; transmission of infectious diseases in animals and plants; negligent provision of veterinary assistance; production of harmful agents for the treatment of animals; contamination of food and water for feeding, ie feeding animals; devastation of forests and the crime of forest 
theft. The fourth category includes two criminal offenses (criminal offenses of illegal hunting and fishing), which include illegal hunting and illegal fishing.

Within the amendments to the now valid Criminal Code, the first of which was in 2009, and the last in 2019 ("Official Gazette of RS” No. 72/2009), " Official Gazette of RS ”, No. 111/2009); 2012, (“Official Gazette of RS”, No. 112/2012); year 2013, (“Official Gazette of RS ”, No. 104/2013); year 2014, “ Official Gazette of RS ”, No. 108/2014); year 2016, “ Official Gazette of RS ”, No. 94/2016); year 2019, and “ Official Gazette of RS", No. 35/2019), for certain criminal offenses, certain changes and additions have been made in terms of penal policy. The Law on Amendments to the Criminal Code of 2009 ("Official Gazette of the RS", No. 72/2009) for criminal offenses of environmental pollution, failure to take environmental protection measures, ingest of dangerous substances into Serbia and illicit processing, disposal and storage of dangerous substances, killing and abuse of animals, and the crime of contamination of food and water for food, ie watering animals, penal policy has been tightened. As for the amendments to the Criminal Code that followed in 2019, it referred only to the crime of killing and abusing animals, in terms of tightening the penal policy, within which the basic form of the crime was the previous prison sentence of up to one year, increased to imprisonment for up to two years, and for the second more serious form of crime the previous lower limit of imprisonment of three months was increased to imprisonment of six months, while the upper limit of up to three years for this form remained unchanged

Crimes against the environment are among the offenses for which, for all acts, prosecution is undertaken ex officio, and imprisonment is determined in the range of up to one to ten years. It is also significant the legal provision according to which the court may, in cases where pronounces a suspended sentence, impose an obligation on the convicted person to take the determined measures for the protection and preservation of the environment, ie measures to eliminate harmful consequences for the environment, which have occurred by committing a crime (Stojanović, Perić, 2002).

\section{Findings of empirical research and discussion}

Empirical research includes scientific statistical, quantitative, qualitative analysis and scientific correlation of findings from available databases / indicators expressed in the number of reported, accused and convicted adults for the period from 2006 to 2017, in the area of the Republic of Serbia.

In (Table 1.) shows the result of the findings from the correlation of the total number of reported, accused and convicted adults for all crimes, in relation to the total number of reported, accused and convicted persons for crimes against the environment. From this research, we find that the number of reported persons for crimes against the environment has a share in the total number of reported persons for all crimes, of only $1.90 \%$, with the number of accused having a share of $2.58 \%$ and the number of convicted $2.44 \%$. Investigating criminal offenses against the environment, we find that 
of the total number of reported persons, $71.18 \%$ were indicted and $50.22 \%$ convicted, while $70.56 \%$ of the total number of accused persons were convicted.

Table 1. Number of reported, accused and convicted adults for all criminal offenses and for criminal offenses against the environment on the territory of the Republic of Serbia

\begin{tabular}{|c|c|c|c|}
\hline Year & Reported persons & Accused persons & Convicted persons \\
\hline 2006 & $105.701-\mathbf{2 . 0 0 9}$ & $55.369-\mathbf{1 . 4 3 0}$ & $41.422-\mathbf{1 . 0 0 9}$ \\
\hline 2007 & $98.702-\mathbf{1 . 8 3 1}$ & $48.903-\mathbf{1 . 2 0 3}$ & $38.694-\mathbf{9 1 7}$ \\
\hline 2008 & $101.723-\mathbf{1 . 8 9 5}$ & $53.035-\mathbf{8 5 8}$ & $42.138-\mathbf{6 3 3}$ \\
\hline 2009 & $100.026-\mathbf{2 . 0 8 1}$ & $50.404-\mathbf{1 . 0 6 8}$ & $40.880-\mathbf{6 1 9}$ \\
\hline 2010 & $74.279-\mathbf{1 . 5 6 8}$ & $27.860-\mathbf{9 1 7}$ & $21.681-\mathbf{3 3 3}$ \\
\hline 2011 & $88.207-\mathbf{1 . 8 0 9}$ & $39.439-\mathbf{6 3 5}$ & $30.807-\mathbf{4 4 9}$ \\
\hline 2012 & $92.879-\mathbf{1 . 8 4 1}$ & $41.621-\mathbf{6 3 2}$ & $31.322-\mathbf{4 3 0}$ \\
\hline 2013 & $91.411-\mathbf{1 . 9 9 6}$ & $45.704-\mathbf{1 . 0 3 9}$ & $32.241-\mathbf{5 0 8}$ \\
\hline 2014 & $92.600-\mathbf{2 . 1 4 8}$ & $48.425-\mathbf{8 9 5}$ & $35.376-\mathbf{5 8 9}$ \\
\hline 2015 & $108.759-\mathbf{2 . 2 0 5}$ & $42.030-\mathbf{7 8 0}$ & $33.189-\mathbf{5 4 9}$ \\
\hline 2016 & $96.237-\mathbf{2 . 5 0 7}$ & $39.610-\mathbf{6 3 1}$ & $32.525-\mathbf{4 7 2}$ \\
\hline 2017 & $90.348-\mathbf{2 . 1 8 7}$ & $37.752-\mathbf{6 1 0}$ & $31.759-\mathbf{5 1 2}$ \\
\hline In total & $1.140 .872-\mathbf{2 4 . 0 7 7}$ & $530.152-\mathbf{1 0 . 6 9 8}$ & $413.034-\mathbf{7 . 0 2 0}$ \\
\hline
\end{tabular}

Source: Republički zavod za statistiku

The (Table 2.) shows the statistical indicators of the total number of reported, accused and convicted adults for crimes against the environment, expressed cumulatively, according to the structure of all crimes. This research shows that the largest number of persons were reported, accused and convicted for criminal offenses from the group of offenses against flora and fauna, namely: forest theft, with a share of $74.39 \%$; killing and abuse of animals, with a share of $7.43 \%$; illegal hunting, with a share of $6.48 \%$, devastation of forests, with a share of $5.71 \%$ and illegal fishing, with a share of $3.10 \%$. The share of the number of persons reported for these criminal offenses comparing to all other criminal offenses against the environment is $97.11 \%$, while the share of the accused is $43.51 \%$, ie the share of convicted $28.56 \%$. Furthermore, the research shows that the highest percentage of lost crimes in the correlation of reported, accused and convicted persons, refers to the crime of killing and abusing animals, which indicates that animal's welfare is greatly endangered (Petrović, Jović, Manojlović, 2018). Namely, out of the total number of reported persons for this crime, only $19.46 \%$ were charged and $13.76 \%$ were convicted. The share of convicts in relation to the accused for this crime is $70.69 \%$, which indicates that the crime is mostly lost in the phase of pre-investigation procedure (rejected criminal report), ie investigation procedure (suspended investigation) and accusation (indictment not filed). 
Table 2. Number of reported, accused and convicted persons according to the structure of criminal offenses

\begin{tabular}{|c|c|c|c|}
\hline Type of criminal offense & $\begin{array}{l}\text { Reported } \\
\text { persons }\end{array}$ & $\begin{array}{l}\text { Accused } \\
\text { persons }\end{array}$ & $\begin{array}{c}\text { Convicted } \\
\text { persons }\end{array}$ \\
\hline Environmental pollution & 154 & 32 & 8 \\
\hline Non-taking measures for environmental protection & 80 & 32 & 15 \\
\hline $\begin{array}{l}\text { Illegal construction and commissioning of } \\
\text { facilities and plants that pollute the environment }\end{array}$ & 8 & 1 & 3 \\
\hline $\begin{array}{l}\text { Damage of buildings and devices for environmental } \\
\text { protection }\end{array}$ & 14 & 2 & 2 \\
\hline Environmental damage & 96 & 40 & 25 \\
\hline $\begin{array}{l}\text { Destruction, damage, taking abroad and bringing } \\
\text { into Serbia a protected natural asset }\end{array}$ & 166 & 61 & 54 \\
\hline $\begin{array}{l}\text { Importation of dangerous substances into Serbia } \\
\text { and illegal processing, disposal and storage of } \\
\text { dangerous substances }\end{array}$ & 20 & 6 & 6 \\
\hline Illegal construction of nuclear plants & 2 & 1 & 1 \\
\hline $\begin{array}{l}\text { Violation of the right to information on the state of } \\
\text { the environment }\end{array}$ & 11 & 0 & 0 \\
\hline Killing and abusing animals & 1788 & 348 & 246 \\
\hline $\begin{array}{l}\text { Transmission of infectious diseases in animals and } \\
\text { plants }\end{array}$ & 28 & 18 & 13 \\
\hline Unconscientious provision of veterinary assistance & 32 & 5 & 0 \\
\hline $\begin{array}{l}\text { Production of harmful agents for the treatment of } \\
\text { animals }\end{array}$ & 14 & 12 & 11 \\
\hline $\begin{array}{l}\text { Contamination of food and water for food, ie } \\
\text { feeding animals }\end{array}$ & 70 & 13 & 6 \\
\hline Forest devastation & 1376 & 640 & 498 \\
\hline Forest theft & 17911 & 8401 & 5344 \\
\hline Illegal hunting & 1561 & 598 & 347 \\
\hline Illegal fishing & 746 & 488 & 441 \\
\hline In total & 24.077 & 10.698 & 7.020 \\
\hline
\end{tabular}

Source:Republički zavod za statistiku

According to the findings from the research in (Table 3.), which refer to the type of decision in the pre-investigation (Jović, 2014) procedure and the investigation procedure for reported persons, according to the structure of all criminal offenses against the environment, we find that in many cases application is rejected. As a percentage, the number of reported persons against whom criminal charges for all crimes against the environment were rejected is $36.01 \%$, while the investigation was terminated in only four cases, and the suspension of the investigation followed in slightly less than $1 \%$. Dismissal in the criminal offenses for which the largest number of persons is reported varies, and those for the offense of forest theft are in amount of $34.48 \%$, for the offense of illegal hunting $45.93 \%$, then for the offense of killing and abusing animals is $35.63 \%$, and for the offense illegal fishing is $30.97 \%$. The findings from the research indicate that the number of rejected criminal charges for criminal offenses belonging to the group of 
general criminal offenses against the environment is the largest, and it is in amounts of $61.06 \%$. These findings, on the one hand, confirm the complexity of proving criminal offenses from this group (Busarčević, et. al., 2001), and on the other hand indicate the need to increase the efficiency of the evidentiary procedure (Lazarević, 2006).

Table 3. Number of registered adults according to the type of decision

\begin{tabular}{|c|c|c|c|}
\hline Type of criminal offense & $\begin{array}{c}\text { Application } \\
\text { rejected }\end{array}$ & $\begin{array}{l}\text { Terminated } \\
\text { investigation }\end{array}$ & \begin{tabular}{|l|} 
Suspended \\
Investigation
\end{tabular} \\
\hline Environmental pollution & 90 & 0 & 2 \\
\hline $\begin{array}{l}\text { Non-taking measures for environmental } \\
\text { protection }\end{array}$ & 54 & 0 & 6 \\
\hline $\begin{array}{l}\text { Illegal construction and commissioning of } \\
\text { facilities and plants that pollute the environment }\end{array}$ & 6 & 0 & 0 \\
\hline $\begin{array}{l}\text { Damage of buildings and devices for } \\
\text { environmental protection }\end{array}$ & 6 & 0 & 1 \\
\hline Environmental damage & 41 & 0 & 1 \\
\hline $\begin{array}{l}\text { Destruction, damage, taking abroad and } \\
\text { bringing into Serbia a protected natural asset }\end{array}$ & 116 & 0 & 0 \\
\hline $\begin{array}{l}\text { Importation of dangerous substances into Serbia } \\
\text { and illegal processing, disposal and storage of } \\
\text { dangerous substances }\end{array}$ & 1 & 0 & 0 \\
\hline Illegal construction of nuclear plants & 1 & 0 & 0 \\
\hline $\begin{array}{l}\text { Violation of the right to information on the state } \\
\text { of the environment }\end{array}$ & 10 & 0 & 0 \\
\hline Killing and abusing animals & 637 & 0 & 12 \\
\hline $\begin{array}{l}\text { Transmission of infectious diseases in animals } \\
\text { and plants }\end{array}$ & 19 & 0 & 0 \\
\hline $\begin{array}{l}\text { Unconscientious provision of veterinary } \\
\text { assistance }\end{array}$ & 15 & 0 & 0 \\
\hline $\begin{array}{l}\text { Production of harmful agents for the treatment } \\
\text { of animals }\end{array}$ & 2 & 0 & 0 \\
\hline $\begin{array}{l}\text { Contamination of food and water for food, ie } \\
\text { feeding animals }\end{array}$ & 17 & 0 & 0 \\
\hline Forest devastation & 532 & 1 & 14 \\
\hline Forest theft & 6176 & 3 & 136 \\
\hline Illegal hunting & 717 & 0 & 24 \\
\hline Illegal fishing & 231 & 0 & 1 \\
\hline In total & 8.671 & 4 & 197 \\
\hline
\end{tabular}

Source: Republički zavod za statistiku

Quantitative qualitative analysis of the findings from (Table 4.), which refers to the type of decision for the accused, finding is that in most of the cases, the accused were found guilty, which makes a total of $69.07 \%$. The number of accused persons against whom the proceedings were suspended is the lowest and it amounts to $8.13 \%$, with the number of accused persons acquitted of the charge being $10.21 \%$, and the number of accused against whom the charge was rejected being $13.68 \%$. Observed by the structure of 
criminal offenses, the number of accused found guilty of the most numerous criminal offenses also varies, and its share for the criminal offense of forest theft is $68.37 \%$, then for the criminal offense of forest devastation $73.59 \%$, for the criminal offense of killing and abusing animals $70.69 \%$, then the crime of illegal hunting $59.25 \%$, or for the crime of illegal fishing $88.73 \%$. Regarding the investigation by groups of criminal offenses, as was the case with the reported persons, the smallest number of accused found guilty relates to general criminal offenses against the environment, and it is $63.69 \%$, which also indicates the need to increase the efficiency of the judiciary procedure and procedure for legal remedies.

Table 4. Number of accused adults by type of decision

\begin{tabular}{|c|c|c|c|c|}
\hline Type of criminal offense & $\begin{array}{l}\text { Procedure } \\
\text { suspended }\end{array}$ & $\begin{array}{l}\text { Acquitted } \\
\text { from } \\
\text { charge }\end{array}$ & $\begin{array}{l}\text { The charge } \\
\text { was denied }\end{array}$ & $\begin{array}{l}\text { Found } \\
\text { guilty }\end{array}$ \\
\hline Environmental pollution & 0 & 16 & 3 & 8 \\
\hline $\begin{array}{l}\text { Failure to take environmental protection } \\
\text { measures }\end{array}$ & 7 & 7 & 4 & 15 \\
\hline $\begin{array}{l}\text { Illegal construction and commissioning } \\
\text { of facilities and plants that pollute the } \\
\text { environment }\end{array}$ & 0 & 0 & 0 & 1 \\
\hline $\begin{array}{l}\text { Damage to buildings and devices for } \\
\text { environmental protection }\end{array}$ & 0 & 0 & 0 & 2 \\
\hline Environmental damage & 4 & 5 & 4 & 27 \\
\hline $\begin{array}{l}\text { Destruction, damage, taking abroad and } \\
\text { bringing into Serbia a protected natural asset }\end{array}$ & 6 & 2 & 3 & 54 \\
\hline $\begin{array}{l}\text { Importation of dangerous substances into } \\
\text { Serbia and illegal processing, disposal } \\
\text { and storage of dangerous substances }\end{array}$ & 0 & 0 & 0 & 6 \\
\hline Illegal construction of nuclear plants & 0 & 0 & 0 & 0 \\
\hline $\begin{array}{l}\text { Violation of the right to information on } \\
\text { the state of the environment }\end{array}$ & 0 & 0 & 0 & 0 \\
\hline Killing and abusing animals & 23 & 46 & 27 & 246 \\
\hline $\begin{array}{l}\text { Transmission of infectious diseases in } \\
\text { animals and plants }\end{array}$ & 2 & 3 & 3 & 12 \\
\hline $\begin{array}{l}\text { Unconscientious provision of veterinary } \\
\text { assistance }\end{array}$ & 0 & 1 & 4 & 0 \\
\hline $\begin{array}{l}\text { Production of harmful agents for the } \\
\text { treatment of animals }\end{array}$ & 1 & 0 & 0 & 5 \\
\hline $\begin{array}{l}\text { Contamination of food and water for food, } \\
\text { ie feeding animals }\end{array}$ & 2 & 3 & 3 & 6 \\
\hline Forest devastation & 43 & 53 & 62 & 471 \\
\hline Forest theft & 690 & 789 & 1265 & 5744 \\
\hline Illegal hunting & 69 & 131 & 58 & 349 \\
\hline Illegal fishing & 23 & 36 & 27 & 443 \\
\hline In total & 870 & 1092 & 1463 & 7389 \\
\hline
\end{tabular}

Source: Republički zavod za statistiku 
Examining the data from (Table 5.), which refer to the imposed criminal sanctions, we find that in most cases, a suspended sentence was imposed against convicted persons, which makes a total of $57.21 \%$. The court reprimand was issued in the smallest number of cases, with a share of $1.45 \%$, while the fine is the second in the number of imposed criminal sanctions and it is $26.35 \%$. Imprisonment was imposed in a small number of cases and it is only $12.83 \%$. From the research related to the structure of imprisonment, we find that in most cases this sentence was imposed for a period of 3 to 6 months, a total of $27.75 \%$, and imprisonment for a term of 2 to 3 months, which is $25.75 \%$. The most severe imprisonment sentence for crimes against the environment is 2 to 3 years, this sentence was imposed in only eleven cases during the investigation period, in seven cases for the crime of forest theft, and in one case for crimes of forest devastation, environmental damage and illegal.

Table 5. Number of convicted adults according to the imposed criminal sanctions

\begin{tabular}{|c|c|c|c|c|}
\hline Type of criminal offense & $\begin{array}{c}\text { Prison } \\
\text { sentence }\end{array}$ & $\begin{array}{l}\text { Amercement } \\
\text { (fine) }\end{array}$ & Probation & $\begin{array}{c}\text { Court } \\
\text { reprimand }\end{array}$ \\
\hline Environmental pollution & 1 & 1 & 7 & 0 \\
\hline $\begin{array}{l}\text { Failure to take environmental } \\
\text { protection measures }\end{array}$ & 6 & 2 & 8 & 0 \\
\hline $\begin{array}{l}\text { Illegal construction and } \\
\text { commissioning of facilities and } \\
\text { plants that pollute the environment }\end{array}$ & 1 & 0 & 0 & 0 \\
\hline $\begin{array}{l}\text { Damage to buildings and devices } \\
\text { for environmental protection }\end{array}$ & 2 & 0 & 1 & 0 \\
\hline Environmental damage & 7 & 3 & 14 & 0 \\
\hline $\begin{array}{l}\text { Destruction, damage, taking } \\
\text { abroad and bringing into Serbia a } \\
\text { protected natural asset }\end{array}$ & 9 & 5 & 40 & 0 \\
\hline $\begin{array}{l}\text { Importation of dangerous } \\
\text { substances into Serbia and illegal } \\
\text { processing, disposal and storage of } \\
\text { dangerous substances }\end{array}$ & 2 & 1 & 3 & 0 \\
\hline $\begin{array}{l}\text { Illegal construction of nuclear } \\
\text { plants }\end{array}$ & 1 & 0 & 0 & 0 \\
\hline $\begin{array}{l}\text { Violation of the right to information } \\
\text { on the state of the environment }\end{array}$ & 0 & 0 & 0 & 0 \\
\hline Killing and abusing animals & 22 & 83 & 126 & 10 \\
\hline $\begin{array}{l}\text { Transmission of infectious diseases } \\
\text { in animals and plants }\end{array}$ & 4 & 3 & 0 & 0 \\
\hline $\begin{array}{l}\text { Unconscientious provision of } \\
\text { veterinary assistance }\end{array}$ & 0 & 0 & 0 & 0 \\
\hline $\begin{array}{l}\text { Production of harmful agents for } \\
\text { the treatment of animals }\end{array}$ & 0 & 1 & 10 & 0 \\
\hline $\begin{array}{l}\text { Contamination of food and water } \\
\text { for food, ie feeding animals }\end{array}$ & 1 & 1 & 4 & 0 \\
\hline Forest devastation & 37 & 170 & 276 & 7 \\
\hline
\end{tabular}




\begin{tabular}{|l|c|c|c|c|}
\hline \multicolumn{1}{|c|}{ Type of criminal offense } & $\begin{array}{c}\text { Prison } \\
\text { sentence }\end{array}$ & $\begin{array}{c}\text { Amercement } \\
\text { (fine) }\end{array}$ & Probation & $\begin{array}{c}\text { Court } \\
\text { reprimand }\end{array}$ \\
\hline Forest theft & 732 & 1372 & 3069 & 77 \\
\hline Illegal hunting & 28 & 106 & 197 & 4 \\
\hline Illegal fishing & 48 & 102 & 261 & 4 \\
\hline In total & 901 & 1850 & 4016 & 102 \\
\hline
\end{tabular}

Source: Republički zavod za statistiku

\section{Conclusion}

The level of criminal protection of the environment during the past years, as the findings from the research indicate, as very low level. Despite the fact that Serbia has adopted a wide range of legal regulations in the field of environmental protection in a relatively short period, it can be noticed that the prosecution has problems with filed criminal charges, which are especially negatively correlated between reported and accused, ie convicted persons.

The findings from the research indicate that judicial and other state bodies are reluctant to engage in proving those criminal offenses thus procedure of proving is complex in nature and requires a higher level of expertise and persistence. The fact that general crimes that endanger the environment the most and whose proof is the most complex, represented only $1.99 \%$ in the total number of crimes in this area, indicates disrespect for the basic constitutional principle relating to the right of everyone to a healthy environment and to timely and complete be informed of her condition.

The competent state authorities obviously deal only with criminal offenses for which they can easily collect material evidence (forest theft, forest devastation, killing and abuse of animals, illegal hunting, illegal fishing), hence these offenses are the most numerous (but with a very mild criminal record policy), while for general criminal offenses against the environment, the proof of which is based on expert findings or other documents, and for which a higher level of expertise and knowledge is necessary, in addition to being insignificant in terms of the number of detected, criminal proceedings are generally not ending with a conviction.

In order to improve the situation in the field of detection and proof of criminal offenses against the environment, it is necessary to apply adequate criminal and penal policy, primarily in the field of recognizing and timely responding to incriminations that endanger the environment, professional training and technical training of bodies and institutions which are involved in the procedure of proving these criminal offenses, especially if we keep in mind the fact that the greatest loss of crime occurs in the phase of pre-investigation procedure, ie the procedure of investigation and accusation.

\section{Conflict of interests}

The authors declare no conflict of interest. 


\section{References}

1. Brock, L. (1991). Peace through parks? The Environment on the Peace Research Agenda. Journal of Peace Research, Sage Journals, 28(4), 407-423.

2. Busarčević, M., Radmilac, D., Krstić, D., Cvetković, LJ., Grušica, B., \& Poljak, Đ. (2001). Osnovi kriminalističkih veštačenja, Ministarstvo unutrašnjih poslova Republike Srbije, Beograd, Srbija. [in English: Busarčević, M., Radmilac, D., Krstić, D., Cvetković, Lj., Grušica, B., \& Poljak, Đ. (2001). Fundamentals of criminal expertise, Ministry of Internal Affairs of the Republic of Serbia, Belgrade, Serbia].

3. Dimitrijević, D. (2010). Trendovi ekološke bezbednosti u XXI veku, Univerzitet u Beogradu, Fakultet bezbednosti, Beograd, Srbija. [in English: Dimitrijević, D. (2010). Environmental safety trends in the XXI century, University of Belgrade, Faculty of Security, Belgrade, Serbia].

4. Radojčić, N. (1960). Zakonik Cara Stefana Dušana 1349. i 1354. Kuća Vid, Beograd, Srbija. [in English: Radojčić, N. (1960). Code of Tsar Stefan Dušan in 1349 and 1354. House Vid, Belgrade, Serbia].

5. Jović, V. (2014). Politika suprotstavljanja ekološkom kriminalitetu u Republici Srbiji i njen uticaj na ekološku bezbednost. Megatrend revija, 11(4), 321-342.

6. Jović, V., Manojlović, D., Milutinović, O., \& Ćemalović, U. (2019). Pravo bezbednosti, Beosing, Beograd, Srbija. [in English: Jović, V., Manojlović, D., Milutinović, O., \& Ćemalović, U. (2019). Security Law, Beosing, Belgrade, Serbia].

7. Lazarević, Lj. (2006). Komentar Krivičnog zakonika Republike Srbije, Savremena administracija, Beograd, Srbija. [in English: Lazarević, Lj. (2006). Commentary on the Criminal Code of the Republic of Serbia, Contemporary Administration, Belgrade, Serbia].

8. Lilić, S., \& Drenovak, M. (2010). Ekološko pravo, Pravni fakultet Univerziteta u Beogradu, Beograd, Srbija. [in English: Lilić, S., \& Drenovak, M. (2010). Environmental Law, Faculty of Law, University of Belgrade, Belgrade, Serbia].

9. Luketić, M., Bujuklić, Ž., \& Vučković, N. (1988). Srednjevjekovni statut Budve, Istririjski arhiv. Anali Budve, Budva, Crna Gora.

10. Lukinović, M., Opačić, A., \& Milojević, I. (2020). Legal aspects of merchandising in sports. Oditor - časopis za menadžment, finansije i pravo, 6(2), 63-76. https:// doi.org/10.5937/Oditor2002063L

11. Petrović. Z., Jović, V., \& Manojlović, D. (2014). Legal protection of land from pollution. Economics of Agriculture, 61(4), 723-735.

12. Petrović, Z., Jović, V., \& Manojlović, D. (2015). Ecological protection of agriculture through Serbia's legal regulations and judicial practice. Economics of Agriculture, 62(2), 649-652. 
13. Petrović, Z., Jović, V., \& Manojlović, D. (2018). Environment and legal protection of animals in the Republic of Serbia. Economics of Agriculture, 65(3), 293-305. https://doi.org/10.5937/ekoPolj1801293P

14. Salzman, J., \& Thompson, B. (2003). Environmental Law and Policy (Concepts and Insights), Foundation Press, New York, USA.

15. Stojanović, Z., Perić, O. (2002). Krivično pravo-posebni deo, Službeni glasnik, Beograd, Srbija.

16. The English Institute of America (1973). International Webster New Encyclopedic Dictionary of English Language, 329, Tabor House, New York, USA.

17. Čejović, B. (2006). Krivično pravo-opšti i posebni deo, Dosije, Beograd, Srbija. [in English: Čejović, B. (2006). Criminal law - general and special part, Dossier, Belgrade, Serbia].

18. Ćemalović, U., \& Jović, V. (2015). L'évolution de la protection de l'environnement dans le processus d'adhésion à l'Union européenne - le cas de la Serbie, Revue trimestrielle de droit européen 2-2015, 328, Dalloz, Paris, Francuska.

19. Krivični zakon („Službeni list FNRJ“, br. 106/1947). [in English: Criminal Code (,Official Gazette of the Federal People's Republic of Yugoslavia”, No. 106/1947.].

20. Krivični zakon (,Službeni list FNRJ“, br. 13/1951). [in English: Criminal Code (“Official Gazette of the Federal People's Republic of Yugoslavia”, No. 13/1951.].

21. Zakon o izmenama i dopunama Krivičnog zakona ("Službeni list FNRJ", br. 30/1959). [in English: Law on Amendments to the Criminal Code ("Official Gazette of the Federal People's Republic of Yugoslavia”, No. 30/1959.].

22. Krivični zakon („Službeni glasnik SRS“, br. 26/1977). [in English: Criminal Code ("Official Gazette of the SRS", No. 26/1977.].

23. Закон о изменама и допунама Кривичног законика („Службени гласник РС“, бр. 39/2003). [in English: Law on Amendments to the Criminal Code ("Official Gazette of RS", No. 39/2003.].

24. Krivični zakonik (Službeni glasnik RS “, br. 85/2005). [in English: Criminal Code, ("Official Gazette of RS", No. 85/2005.].

25. Zakon o izmenama i dopunama Krivičnog zakonika, (,Službeni glasnik RS“, br. 72/2009"). [in English: Law on Amendments to the Criminal Code ("Official Gazette of RS", No. 72/2009.].

26. Zakon o izmenama i dopunama Krivičnog zakonika, („Službeni glasnik RS“, br. 111/2009"). [in English: Law on Amendments to the Criminal Code ("Official Gazette of RS", No. 111/2009.].

27. Zakon o izmenama i dopunama Krivičnog zakonika, (,Službeni glasnik RS“, br. 112/2012"). [in English: Law on Amendments to the Criminal Code ("Official Gazette of RS", No. 112/2012.]. 
28. Zakon o izmenama i dopunama Krivičnog zakonika, (,Službeni glasnik RS“, br. 104/2013“). [in English: Law on Amendments to the Criminal Code ("Official Gazette of RS", No. 104/2013.].

29. Zakon o izmenama i dopunama Krivičnog zakonika, („Službeni glasnik RS“, br. 108/2014"). [in English: Law on Amendments to the Criminal Code ("Official Gazette of RS", No. 108/2014.].

30. Zakon o izmenama i dopunama Krivičnog zakonika, („Službeni glasnik RS“, br. 94/2016“). [in English: Law on Amendments to the Criminal Code ("Official Gazette of RS", No. 94/2016.].

31. Zakon o izmenama i dopunama Krivičnog zakonika, („Službeni glasnik RS“, br. 35/2019“). [in English: Law on Amendments to the Criminal Code ("Official Gazette of RS", No. 35/2019.].

32. Republički zavod za statistiku-Republika Srbija: Bilteni: „Punoletni počinioci krivičnih dela - prijave, optužbe, osuđujuće presude: Bilten, br. 490/2006; Bilten br. 502/2007; Bilten, br. 514/2008; Bilten, br. 529/2009; Bilten, br. 546/2010; Bilten, br. 558/2011; Bilten br. 576/2012; Bilten, br. 588/2013; Bilten, br. 603/2014; Bilten, br. 617/2015; Bilten, br. 629/2016; Bilten, br. 643/2017. [in English: Bureau of Statistics-Republic of Serbia: Bulletins: „Adult perpetrators of criminal offenses reports, charges, convictions“: Bulletin, No. 490/2006; Bulletin, No. 502/2007; Bulletin, No. 514/2008; Bulletin, No. 529/2009; Bulletin, No. 546/2010; Bulletin No. 558/2011; Bulletin, No. 576/2012; Bulletin, no. 588/2013; Bulletin, No. 603/2014; Bulletin, No. 617/2015; Bulletin, No. 629/2016; Bulletin, No. 643/2017.]. 